\title{
An Ethno Pharmacological New Strategy for Discovery of Potential Antihypertensive Plants in Cameroon
}

\section{Tsabang $\mathbf{N}^{*}$}

Center for Research on Medicinal Plants and Traditional Medicine, Institute of Medical Research and Medicinal Plants Studies, Cameroon

*Corresponding author: Tsabang N, Center for Research on Medicinal Plants and Traditional Medicine, Institute of Medical Research and Medicinal Plants Studies, P.O. Box 6163, Yaounde, Cameroon, Tel: (273) 67746 16; E-mail: tsabang2001@yahoo.fr

Received date: November 01, 2016; Accepted date: November 23, 2016; Published date: November 26, 2016

Copyright: ( 2016 Tsabang N. This is an open-access article distributed under the terms of the Creative Commons Attribution License, which permits unrestricted use, distribution, and reproduction in any medium, provided the original author and source are credited.

\begin{abstract}
Objective: Manifold plants are documented in the world, but arterial hypertension still an important public health challenge in both developing and developed countries. Therefore the objective of the study is to identify several herbal medicines used in the treatment of arterial hypertension in Cameroon.

Methods: The survey was undertaken between 2003 and 2016 with the aim of establishing a new ethnopharmacological strategy for identifying potential antihypentive plants in Cameroon's population. Three phytogeographic areas in which live 1131 randomly screened interviewees distributed in 58 socio-cultural groups were involved in this study. In the first phytogeographic area live 293 interviewers distributed in 16 socio-cultural groups. In the second live 277 interviewees distributed in 14 socio-cultural groups and in the third live 561 interviewees distributed in 23 socio-cultural groups. The survey was successfully achieved, using a cluster sampling procedure in each ethnic group. The potential anti arterial hypertensive plants were selected using an extended criterion of identification of suspected anti arterial hypertensive plants and suspected arterial hypertensive patients defined as follow: if a single plant is used to treat three signs, three symptoms and/or three complications of arterial hypertension, we considered it as an anti-arterial hypertensive plants and the person who presented these three signs, three symptoms and/or three complications is a suspected arterial hypertensive patient.
\end{abstract}

Results: The observation of $24.39 \%$ of suspected arterial hypertensive patients relieved by traditional healers' symptomatic treatments and $50 \%$ of recorded suspected anti arterial hypertensive plants that were confirmed by previous pharmacological studies, showed promising perspectives for the criterion used.

Conclusion: The data provide evidence that potential anti arterial hypertensive plants are common in Cameroon more than usual anti arterial hypertensive species. They should serve as plants documented for the new anti-arterial hypertensive drugs discovery for the prevention and control of this disease worldwide.

Keywords: Cameroon; Ethno pharmacological; Traditional healers; Potential arterial; Antihypertensive plants

\section{Introduction}

Arterial hypertension is the pathological increasing of blood pressure. A person is hypertensive when systolic blood pressure is superior to $140 \mathrm{mmHg}$ or when diastolic blood pressure is superior to $90 \mathrm{mmHg}$. For the American Heart Association blood pressure is less than 140 over 90 normal for adults. However, the National Heart, Lung, and Blood Institute lows the standard normal readings to less than 120 over less than 80 in 2003 [1,2]. Hypertension is a major health problem, especially because it is symptomless pathology. Numerous people have unconsciously raised blood pressure without knowing it [1]. About 80 million Americans' adults live with hypertension [1].

In African countries, where many settled people don't usually control their blood pressure, high blood pressure can damage their health. This lifestyle may increase the prevalence of increasing hypertension around the world. For this fundamental reason, the administrators of district of Fongo-Tongo (Cameroon) render obligatory the physical training in their commandment's territory. The regular consultation of medical doctors is another solution for many people to know their high blood pressure state. These measures will reduce the frequency of cardiovascular diseases including arterial hypertension and increase the rate of conscious arterial hypertensive patients that was reported for $46 \%$ of the studies and that varied from $25.2 \%$ in Korea to $75 \%$ in Barbados [3]. The lowest prevalence is observed in rural India (3.4\% in men and $6.8 \%$ in women). Poland has the highest prevalence ( $68.9 \%$ in men and $72.5 \%$ in women).

In Cameroon, high blood pressure is frequent. In fact, the crude prevalence reported by the National Epidemiology Board was: 1) $\mathrm{HTN}_{1}: 21,1 \%$ in females and $26.8 \%$ in males. 2) $\mathrm{HTN}_{2}: 10.9 \%$ in females and $13.2 \%$ in males [4]; the age-standardized prevalence was $16.4 \%$ (95\% CI: $11.6-21.2$ ) in urban men and $12.1 \%$ (95\% CI: 7.9-16.2) in urban women; while it was 5.4\% (95\% CI: 2.9-8.0) in rural men and 5.9\% (95\% CI: 3.8-8.0) in women [5]. This prevalent was significantly higher in the urban than in the rural area [5]. The age-adjusted prevalence rate of hypertension wavered from $24.4 \%$ to $37.2 \%$ in men and from $20.1 \%$ to $37.5 \%$ in women [6]. A rate of up to $47.5 \%$ of the hypertension's prevalence was reported in a self-selected urban population in Cameroon [6]. These figures are favourite for the application of the criterion that we used in Cameroon. 
Page 2 of 5

The high prevalence of arterial hypertension renders this disease as an important public health confront worldwide and as a most important modifiable risk factor for cardiovascular, cerebrovascular and kidney failure [7-9]. According to the comparative Risk Assessment Collaborating Group hypertension is the principal global risk factor for mortality and the third leading risk factor for disease burden [10]. Hypertension is the major cause of morbidity and mortality in the economically developed world. Meanwhile, the importance of hypertension in economically developing countries is less well established [10]. In different world regions, previous reviews have reported on the prevalence of hypertension $[11,12]$.

The global burden of hypertension's quantification would allow public health policy to assign sufficient priority and resources for its management and prevention. Numerous studies have been conducted worldwide to record anti arterial hypertensive plants. In some African Sub-Sahara countries few plants have be studies for the treatment of hypertension [12]. In other countries and regions, published information on the anti-arterial hypertensive species is sparse or may not exist. All these studies don't focus on the treatment of signs, symptoms and/or complications of arterial hypertension. The purpose of this study was to assemble experience from socio-cultural groupsbased on anti-arterial hypertensive plants in three phytogeographic areas of Cameroon in order to record potential anti arterial hypertensive from plants used in the treatment of signs, symptoms and/or complications of arterial hypertension.

\section{Methodology}

This study is focus on the fact that many interviewers don't know arterial hypertension but treat it through its signs, symptoms and/or complications that they can easily identify. Also these signs, symptoms and/or complications of arterial hypertension can be found in other diseases like diabetes, then we consider only manifestations more encountered in the study of arterial hypertension [13,14]. Three phytogeographic areas in which live 1131 randomly screened interviewers distributed in 58 sociocultural groups were involved in this study. In the first phytogeographic area live 293 interviewers distributed in 16 socio-cultural groups. In the second live 277 interviewers distributed in 14 socio-cultural groups and in the third 561 interviewees live in 23 socio-cultural groups (Figure 1). Five of these groups below at least to two phytogeographic areas.

The survey was successfully achieved in all the Cameroon, using a cluster sampling procedure in each ethnic group. The potential anti arterial hypertensive plants were select using an extended criterion of identification of anti-arterial hypertensive plants and suspected arterial hypertensive patients defined as follow: If a single plant is used to treat three signs, three symptoms and/or three complications of arterial hypertension, we considered it as an anti-arterial hypertensive plants and the person that presented these three signs, three symptoms and/or three complications is a suspected arterial hypertensive patient.

The survey started by a fieldwork focusing on identification of patients, harvest and identification of plants, following by the ethnopharmacological detailed preparations, the description of recipes and the ethnomedical modes of administration, the posology, the duration of treatment, the undesirable or secondary and toxic effects. The chemical and pharmacological investigation focuses on previous searches were followed. Botanical samples were identified and/or confirmed in National Herbarium of Cameroon. Samples of plants recorded were deposited in the Institute of Medical Research and
Studies of Medicinal Plants [15]. Information on ethnic folklore practices and traditional aspects of therapeutically important herbal medicines were collected using an ethnopharmacological data form presented at the end of the work.

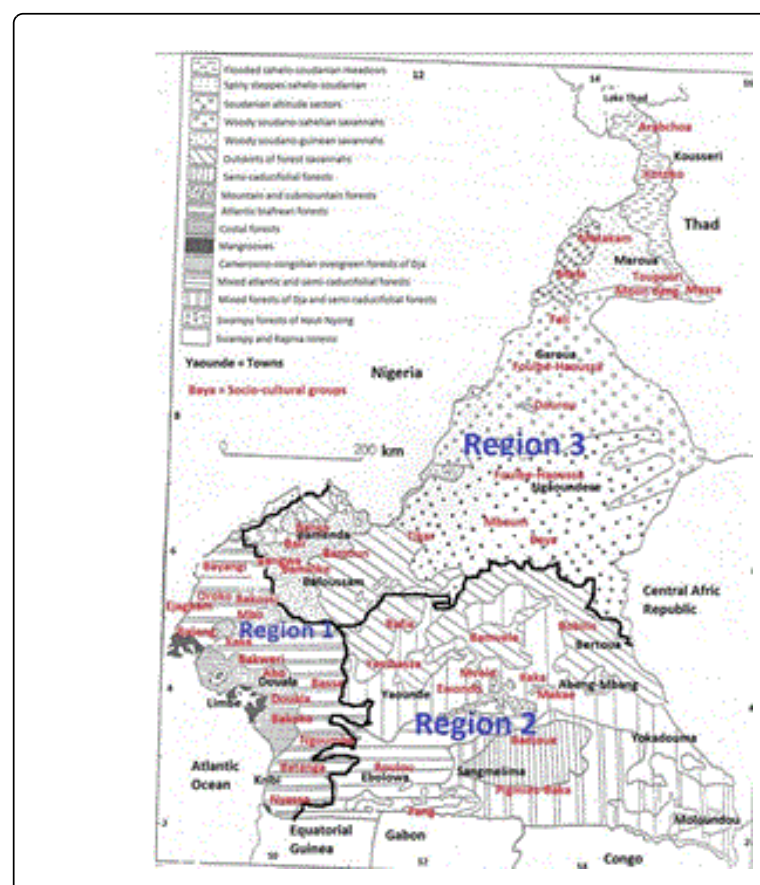

Figure 1: Relationship between socio-cultural groups of interviewers and different phytogeographic units of Cameroon $[15,16]$.

\section{Statistical Analysis}

The interviewees were divided into groups. The group 1 was constituted of interviewees who don't know arterial hypertension, but treat them through its signs, symptoms and complications and group 2 constituted of interviewees who know arterial hypertension. The two were compared using the comparison of a percentage based on a large sample of size $n>30$ with a known standard [16].

\section{Results}

Recorded suspected patients at traditional healers.

Forty-one (41) suspected patients and 14 suspected plants were recorded (Table 1).

\begin{tabular}{|l|l|l|l|l|l|l|}
\hline \multirow{2}{*}{ Number } & \multicolumn{3}{|l|}{ Suspected patients } & \multicolumn{3}{l|}{ Suspected plants } \\
\cline { 2 - 7 } & SHP & S(H-D)P & Total & PSHP & PS(H-D)P & Total \\
\cline { 2 - 7 } & 28 & 13 & 41 & 9 & 6 & 14 \\
\hline $\begin{array}{l}\% \text { of suspected hypertensive patients } \\
\text { relieved by suspected Plants 24,39 }\end{array}$ & $\begin{array}{l}\% \text { of plants with confirmed } \\
\text { antihypertensive effects 50 }\end{array}$ \\
\hline
\end{tabular}

Table 1: Distribution of suspected patients and suspected plants used for suspected patients' treatment at traditional healers. SHP: Suspected Hypertensive Patients; S(H-D)P: Suspected Hypertensive Patient with Diabetes, PSHP: Suspected Plants used for the treatment of Suspected 
Hypertensive Patients; PS(H-D)P: Suspected Plants used for the treatment of Suspected Hypertensive Patient with Diabetes.

Three of suspected recorded plants that improved the health condition of suspected hypertensive patients with diabetes have showed the confirmation of their hypotensive activities by previous pharmacological studies. These plants are: Allium cepa. [17], Persea americana [18] and Catharanthus roseus [17]. Seven identified plants that improved the health condition of 4 suspected hypertensive patients have showed the confirmation of their hypotensive properties by previous pharmacological researches. These plants include Holarrhena floribunda [19], Funtumia elastica, Voacanga africana, and Rauvolfia vomitoria [17].

\section{Efficiency of extended diagnostic criterion of hypertension}

We discovered that ten of 41 suspected patients above $(7$ suspected arterial hypertensive patients and 3 suspected arterial hypertensive with diabetes patients), implying $24.39 \%$ were previously diagnosed in hospitals; where they were hospitalized at least one for arterial hypertension. The suspected or indirect treatment of traditional healers received by them improved often their health condition. Then like 12 others suspected arterial hypertensive patients, they asserted to have regularly satisfaction. So the criterion of suspected patients and suspected plants are conclusive.

The signs, symptoms and complications of arterial hypertension regularly observed are stress, illusion of flies' flight before eyes, hematuria (blood in urine), buzzing ears; insomnia, dysuria, acute oedema, burn urination, cardiac palpitations, angina, dizziness, fatigue or confusion, irregular heartbeat, pounding in the chest, neck or ears, nosebleeds or nasal haemorrhages, severe headaches, severe anxiety and shortness of breath.

\section{Comparison between the two groups of interviewees}

The survey reveals two groups of interviewees. The group of 791 interviewees, who don't know arterial hypertension, but treat it through its signs, symptoms and complications and the group of 340 interviewees who know diabetes. We have used the comparison of a percentage based on a large sample of size $n>30$ with a known standard that involves a binomial distribution. We find 340 of interviewees who know arterial hypertension out of a total of 1131 informants. The variance of this test is $\mathrm{v}=\mathrm{pq} / 1131=1 / 2 \times 1 / 2 / 1131=0.0002$ and the standard error is $=0.0148$. The observed value is $340 / 1131=0.3006$. We find also 791 of interviewees who don't know arterial hypertension out of a total of 1131 informants. The observed value is $791 / 1131=0.6993$.

The difference between the hypothetical value $(0.5000)$ and the observed values is $0.5000-0.3006=0.1994$ or $0.6993-0.5000=0.1993$, this difference is in the two cases appreciably greater than 2, 6 times the corresponding standard error. According to the definition we conclude that there is significant evidence between the two groups at the 5 per cent level. The people who don't know arterial hypertension are more important than those who know it. The survey was conducted more in towns, where many people are supposed to know arterial hypertension through the contact with many arterial hypertensive patients, the visits to hospitals and the influence of medical doctors. Why the number of interviewees who don't know the arterial hypertension is more raised than interviewees who know this pathology? The arterial hypertension is largely a symptomless disease and then it is difficult to diagnose in sociocultural medicine.

According to the respondents, the anthropological aspects of arterial hypertension described for responding also this question were found in the beliefs of population. Indeed $62 \%$ of respondents considered arterial hypertension as a mystic disease. They believed that the coma (Menoubia), the numbness (Aloute me kouc), the dermal clues (Emock Dem), the gangrenes (Ta-Nteu Nfeung), the retinopathy (Meneck Se'eung), the nephropathy (Letse kekan) and the cardiac complications like arteriosclerosis (Ate'eu ngan net) and the grave noose bleeding (Ta-Nteu Afifi), were linked to the suffering of patients' totems, killed by the traditional sporting-gun or victim of a grave fall in the invisible world. The above vernacular names in brackets were the complications' designations in Bamileke. At these state of the disease, the patients were usually considered as sorcerers and the complications they developed came from their expeditions in the invisible world.

The patients could also suffer from severe attacks of witchcraft, the punishments of ancestors, the maledictions or the false gods. Then these false gods must be appeased at all costs. Likewise, the gangrenes of the foot and the benumbed inferior members came from the stampings of conspicuous or invisible poisons. The paralysis and the hemiplegic attacked bewitched patients [20]. These considerations can't facilitate the diagnostic of arterial hypertension by local people.

All recipes used by traditional healers are described in detail in Table 2.

\section{Discussion}

People know a few arterial hypertensive signs; symptoms, complications and plants used for their treatment. But the interview of a strong number of people living in three phytogeographic areas and in 58 socio-cultural groups and the use of the criterion defined in methodology, gave the opportunity to identify some anti-arterial hypertensive plants with suspected positive effect on certain signs, symptoms and complications. The observation of $24.39 \%$ of suspected arterial hypertensive patients relieved by traditional healers' symptomatic treatments and 50\% of recorded suspected anti arterial hypertensive plants that were confirmed anti arterial hypertensive plants by previous pharmacological studies, showed promising perspectives for the criterion used. But arterial hypertension is insipid disease that is briskly trigged and slowly evolved. Then arterial hypertension is largely a symptomless disease. Its manifestations are usually silent. That's why people must know that there is a common misconception that unknown patients with arterial hypertension will experience symptoms, especially those that were used to select suspected plants and suspected arterial hypertensive patients. If someone ignores his blood pressure measures because signs and symptoms will alert him to the complications, he is taking a dangerous rick with his life. The criterion that we use will be more applicable if everyone knows his blood pressure numbers and normal people will try to prevent hypertension from developing [21-24].

Another difficulty on the application of the criterion is coming from the multifaceted causes of some arterial hypertension' symptoms including dizziness that can be a side effect of some high blood pressure herbal medicines and patients should not be ignored; particularly if they notice a sudden onset [21-24]. 
Citation: Tsabang N (2016) An Ethno Pharmacological New Strategy for Discovery of Potential Antihypertensive Plants in Cameroon. Pharm Anal Acta 7: 517. doi:10.4172/2153-2435.1000517

Page 4 of 5

\begin{tabular}{|c|c|c|c|c|c|c|}
\hline $\begin{array}{l}\text { Scientific names Vernacular } \\
\text { names Common names }\end{array}$ & $\begin{array}{l}\text { Signs, symptoms and } \\
\text { complications }\end{array}$ & QPMU in gram & TPQS in liter & TP in $\mathbf{m n}$ & RQHTD & DT \\
\hline \multicolumn{7}{|c|}{ Phytogeographic area 1 corresponding to Coastal humid rain forests } \\
\hline 1-Funtumia elastica & $\begin{array}{l}\text { Fatigue and confusion, chest- } \\
\text { affections, heart conditions, and } \\
\text { chronic obstructive pulmonary } \\
\text { disease }\end{array}$ & $150 \mathrm{~g}$ of leaves & $\begin{array}{l}\text { Decoction in } 2 \mathrm{~L} \text { of } \\
\text { water }\end{array}$ & 10 & $\begin{array}{l}\text { Drink } 250 \mathrm{~mL} \quad 4 \text { times } \\
\text { daily }\end{array}$ & 7 \\
\hline 2-Holarrhena floribunda & $\begin{array}{l}\text { Irregular Heartbeat, respiratory } \\
\text { analeptic, swellings, oedema }\end{array}$ & $\begin{array}{l}4 \text { table spoons } \\
\text { of stem bark or } \\
\text { of root's power }\end{array}$ & $\begin{array}{l}\text { Decoction in } 1.5 \mathrm{~L} \text { of } \\
\text { water }\end{array}$ & 15 & $\begin{array}{l}\text { Drink } 250 \mathrm{~mL} 2 \text { times } \\
\text { daily }\end{array}$ & 7 \\
\hline 3-Catharanthus roseus & $\begin{array}{l}\text { Hematuria, insomnia, } \\
\text { headaches and fatigue, buzzing } \\
\text { of ears, complications of lung or } \\
\text { kidney }\end{array}$ & $\begin{array}{l}80 \mathrm{~g} \text { leaves or } \\
100 \mathrm{~g} \text { of stem } \\
\text { bark }\end{array}$ & $\begin{array}{l}\text { Maceration in } 3 \mathrm{~L} \text { of } \\
\text { water }\end{array}$ & - & $\begin{array}{l}\text { Drink } 250 \mathrm{~mL} 2 \text { times } \\
\text { daily }\end{array}$ & 7 \\
\hline 4-Voacanga africana & $\begin{array}{l}\text { Heart-troubles (spasms, } \\
\text { angina), a strengthener; fatigue } \\
\text { due to shortness of breath, } \\
\text { oedema, insomnia, }\end{array}$ & $\begin{array}{l}300 \mathrm{~g} \text { of stem } \\
\text { bark and root } \\
\text { or } 100 \mathrm{~g} \text { leaves }\end{array}$ & $\begin{array}{l}\text { Decoction in } 4 \mathrm{~L} \text { of } \\
\text { water }\end{array}$ & - & $\begin{array}{l}\text { Drink } 250 \mathrm{~mL} 3 \text { times } \\
\text { daily. The sap of the } \\
\text { leaves is used as nose- } \\
\text { drops in treating insanity } \\
\text { The leaf decoction is } \\
\text { used in baths to treat } \\
\text { general; }\end{array}$ & 7 \\
\hline \multicolumn{7}{|c|}{ Phytogeographic area 2 corresponding to continental humid rain forest } \\
\hline 5-Picralima nitida & Chest pain or angina, fatigue & A fruit & Eat a fruit & - & $\begin{array}{l}\text { Every } 6 \mathrm{~h} \text {. Secondary } \\
\text { effect bitterness }\end{array}$ & 7 \\
\hline 6-Allium cepa & $\begin{array}{l}\text { Cardiovascular diseases, } \\
\text { insomnia, Severe anxiety }\end{array}$ & $150 \mathrm{~g}$ of bulb & $\begin{array}{l}\text { Decoction in } 2 \mathrm{~L} \text { of } \\
\text { water }\end{array}$ & - & $\begin{array}{l}\text { Drink } 250 \mathrm{~mL} 2 \text { times a } \\
\text { day }\end{array}$ & 10 \\
\hline 7-Rauvolfia vomitoria & $\begin{array}{l}\text { Insomnia, palpitations of the } \\
\text { heart, dysuria, oedema }\end{array}$ & $\begin{array}{l}50 \mathrm{~g} \text { of fresh } \\
\text { leaves and } 150 \\
\mathrm{~g} \text { of stem bark }\end{array}$ & $\begin{array}{l}\text { Decoction in } 2.5 \mathrm{~L} \text { of } \\
\text { water }\end{array}$ & 15 & $\begin{array}{l}\text { Drink } 250 \mathrm{~mL} 1 \text { time a } \\
\text { day }\end{array}$ & 7 \\
\hline 8-Alchornea cordifolia & $\begin{array}{l}\text { Shortness of breath, oedema, } \\
\text { unconscious persons (coma) }\end{array}$ & $50 \mathrm{~g}$ stem bark & $\begin{array}{l}\text { Maceration in } 1 \mathrm{~L} \text { of } \\
\text { water }\end{array}$ & $6 \mathrm{~h}$ & $\begin{array}{l}\text { Drink } 250 \mathrm{~mL} 2 \text { times a } \\
\text { day }\end{array}$ & 7 \\
\hline 9-Zanthoxylum macrophylla & $\begin{array}{l}\text { Headache, } \\
\text { vasodilatation, and } \begin{array}{r}\text { dysuria, } \\
\text { cardiac }\end{array}\end{array}$ & $\begin{array}{l}50 \mathrm{~g} \text { fresh } \\
\text { leaves }\end{array}$ & $\begin{array}{l}\text { Infusion of in } 2 \mathrm{~L} \text { of } \\
\text { water }\end{array}$ & $6 \mathrm{~h}$ & $\begin{array}{l}\text { Drink } 250 \mathrm{~mL} 4 \text { times a } \\
\text { day }\end{array}$ & 7 \\
\hline 10-Ocimum gratissimum & $\begin{array}{l}\text { Stroke, revive unconscious } \\
\text { persons (coma), pounding in } \\
\text { the chest or ears }\end{array}$ & $\begin{array}{l}150 \mathrm{~g} \text { of stem } \\
\text { bark }\end{array}$ & $\begin{array}{l}\text { Decoction in } 2.5 \mathrm{~L} \text { of } \\
\text { water }\end{array}$ & 30 & $\begin{array}{l}\text { Drink } 250 \mathrm{~mL} 3 \text { times a } \\
\text { day }\end{array}$ & 7 \\
\hline 11-Azadirachta indica & $\begin{array}{l}\text { Cardiovascular diseases } \\
\text { (diabetes) severe anxiety }\end{array}$ & $\begin{array}{l}200 \mathrm{~g} \text { of stem } \\
\text { bark }\end{array}$ & $\begin{array}{l}\text { Decoction in } 3 \mathrm{~L} \text { of } \\
\text { water }\end{array}$ & 15 & $\begin{array}{l}\text { Drink } 250 \mathrm{~mL} 3 \text { times a } \\
\text { day }\end{array}$ & 7 \\
\hline \multicolumn{7}{|c|}{ Phytogeographic area 2 corresponding to guinean, soudano-zamdesian savannahs } \\
\hline 12-Persea Americana & $\begin{array}{l}\text { Dysuria, abundant urination, } \\
\text { brun urination, stress }\end{array}$ & 150 of leaves & $\begin{array}{l}\text { Decoction in } 2.5 \mathrm{~L} \text { of } \\
\text { water }\end{array}$ & 15 & $\begin{array}{l}\text { Drink } 250 \mathrm{~mL} 3 \text { times a } \\
\text { day }\end{array}$ & 10 \\
\hline 13-Piper guineense & $\begin{array}{l}\text { Chest pains, breathing and } \\
\text { heart problems, urinary and } \\
\text { reproductive disorders }\end{array}$ & $200 \mathrm{~g}$ of fruit & $\begin{array}{l}\text { Decoction in } 2.5 \mathrm{~L} \text { of } \\
\text { water }\end{array}$ & 15 & $\begin{array}{l}\text { Drink } 250 \mathrm{~mL} 3 \text { times a } \\
\text { day }\end{array}$ & 7 \\
\hline 14-Albizia adianthifolia & $\begin{array}{l}\text { Dysuria, improve memory, eye } \\
\text { complaints, } \\
\text { complaints, }\end{array}$ & $\begin{array}{l}250 \mathrm{~g} \text { of stem } \\
\text { bark }\end{array}$ & $\begin{array}{l}\text { Decoction in } 2.5 \mathrm{~L} \text { of } \\
\text { water }\end{array}$ & 15 & $\begin{array}{l}\text { Drink } 250 \mathrm{~mL} 3 \text { times a } \\
\text { day }\end{array}$ & 7 \\
\hline
\end{tabular}

Table 2: Detailed ethno pharmacological preparation of recipes. QPMU: Quantity of Plant Material Used; TPQS: Types of Preparation and Quantity of Solvent; TP: Time of Recipes' Preparation; RQHTD: Route of Administration and Quantity of Herbal Taken per Dose; DT: Duration of Treatment in Day.

Normally, the application of the criterion that we used may take in consideration the fact that sudden dizziness, loss of balance or coordination and trouble on foot are all warning signs of a stroke which is one of the most important risk factor for stroke [24]. Also the 
symptoms of hypertensive crisis including include systolic of 180 or higher or diastolic of 110 or higher, provoke the development of severe headaches, severe anxiety, shortness of breath and nosebleeds [25]. In these cases the used of the criterion to select suspected patients and suspected plants will be more adequate.

Treatments based on signs, symptoms and/or complications of arterial hypertension that practice the traditional healers may be useful for possible early diagnostic, if the healers recommend patients to consult medical doctors before the treatment.

\section{Conclusion}

This study reveals that 14 recorded suspected plants were used by traditional healers to treat 41 suspected arterial hypertensive patients. A percentage of $24.39 \%$ of patients were relieved and $50 \%$ of suspected arterial hypertensive plants were confirmed as anti-arterial hypertensive plants by previous pharmacological studies. These results showed promising perspectives for the criterion used and constitute an important method for early diagnostic, if the traditional healers recommend their patients to consult medical doctors before the treatment. Therefore for better investigation in the future this work needs the collaboration between traditional healers, ethnobotanists, chemists and medical doctors.

\section{Acknowledgment}

Thanks are expressed to householders met in the field which have participated and collaborated to the realization of this work, to Bioresources Development and Conservation Programme-Cameroon (BDCP-C) for the training courses that we receive on the field of ethnobiology and to Professor Koueke Paul, retired Professor of Faculty of Medicine and Bio-medical Sciences, University of Yaounde 1 for precious supervision of this work.

\section{References}

1. http://www.who.int/topics/hypertension/en/

2. http://www.heart.org/HEARTORG/Conditions/HighBloodPressure/ AboutHighBloodPre

3. Kearney PM, Whelton M, Reynolds K, Whelton PK, He J (2004) Worldwide prevalence of hypertension: a systematic review. J Hypertens 22: 11-19.

4. Kingue S, Befidi-Mengue R, Angwafor III F, Abbenyi AS, Wansi E, et al. (1996) Prevalence of Hypertension in Cameroon. Preliminary Results of the Cameroon National Health Survey (CNHS).

5. Mbanya JCN, Minkoulou BEM, Salah JN, Balkau B (1998) The prevalence of hypertension in rural and urban Cameroon. Int J Epidem 27: 181-185.

6. Samuel K, Constant NN, Alain Patrick M, Ahmadou MJ, Jean Jacques NN, et al. (2015) Prevalence and Risk Factors of Hypertension in Urban
Areas of Cameroon: A Nationwide Population-Based Cross-Sectional Study. J Clin Hypertens 17: 819-824.

7. He J, Whelton P (1997) Epidemiology and prevention of hypertension. Medical Clinics of North America 81: 1077-1097.

8. Whelton PK (1994) Epidemiology of hypertension. Lancet 344: 101-106.

9. Ezzati M, Lopez AD, Rodgers A, Vander Hoorn S, Murray CJL (2002) The Comparative Risk Assessment Collaborating Group Selected major risk factors and global and regional burden of disease. The Lancet 360: 1347-1360.

10. Ibrahim MM, Damasceno A (2012) Hypertension in developing countries. The Lancet 41: 141-153.

11. Fuentes R, Ilmaniemi N, Laurikainen E, Tuomilehto J, Nissinen A (2000) Hypertension in developing economies: a review of population-based studies carried out from 1980 to 1998. J Hypertens 18: 521-529.

12. Wolf-Maier K, Cooper RS, Banegas JR, Giampaoli S, Hense H, et al. (2003) Hypertension prevalence and blood pressure levels in 6 European countries, Canada, and the United States. JAMA 289: 2363-2369.

13. Digeos-Hasnier S, Girerd X, Le Heuzey JY (2002) Guide pratique de l'Hypertension artérielle. Editions Médicales Spécialisées, 2 Rue Beranger 75003, Paris, p: 246.

14. Upjohn (1963) Diabetes, a monograph on diabetes mellitus, Upjohn Company, Kalamazoo, Michigan, p: 260.

15. Tsabang N, Ngah N, Estella FT, Agbor GA (2016) Herbal Medicine and Treatment of Diabetes in Africa: Case Study in Cameroon. Diabetes Case Rep 1: 112.

16. Tsabang N, Tsabang D, Lionel W, Tsabang F, Cedrix S, et al. (2016) Ethnomedical and Ethnopharmacological Study of Plants Used For Potential Treatments of Diabetes and Arterial Hypertension by Indigenous People in Three Phytogeographic Regions of Cameroon. Diabetes Case Rep 1: 110.

17. Norman TJ, Bailey M (1992) Statistical methods in biology, Second edition, Cambridge University Press, pp: 37-38.

18. Tsabang N (2008) Etude ethnobotanique des plantes à vertus antidiabétiques et/ou antihypertensives au Cameroun, p: 393.

19. Bep OB (1986) Medicinal plants in Tropical West-Africa. Cambridge University Press. Cambridge, New York, p: 375.

20. Tsabang N, Fongnzossie E, Donfack D, Yedjou CG, Tchounwou PB, et al. (2016) Comparative Study of Epidemiological and Anthropological Aspects of Diabetes and Hypertension in Cameroon. Forest Res 5: 165.

21. Berhaut J (1975) Flore illustrée du Sénégal, Dicotylédones, Ficoidées à Mimosacées. Gouvernement du Sénégal, Ministère du développement rural et de l'Hydraulique. Direction des eaux et forêts Dakar, Tome 4: 575.

22. Paris RR, Moyse H (1971) Précis de matières médicales : collection de précis de pharmacie, Pharmacognosie spéciale, dicotylédone (suite) gamopétales. Masson et Cie, Editeurs Paris Vie, Tome 3: 509.

23. http://www.heart.org/HEARTORG/Conditions/HighBloodPressure/ SymptomsDiagn

24. Steve Kim (2016) High Blood Pressure Symptoms.

25. http://www.webmd.com/hypertension-high-blood-pressure/guide/ hypertension 